\title{
ガスクロマトグラフィー一質量分析法による高純度 パルミチン酸中の微量不純物の定量
}

\author{
（1978 年 9 月 1 日 受理）
}

本道子・丸山 正生*

市肘の高純度バルミンン酸中の不純物をガスクロマトグラフィー一筫量分析法により同定，定量した。 これらの不純物として脂肪酸 $\left(\mathrm{C}_{n} \mathrm{H}_{2 n+1} \mathrm{COOH}, n=8 \sim 18\right)$, アルカン $\left(\mathrm{C}_{n} \mathrm{H}_{2 n+2}, n=15 \sim 24\right)$, フルケン同 族体 $\left(\mathrm{C}_{n} \mathrm{H}_{2 n}, n=15 \sim 19\right)$ の 20 種が筫量スベクトルおよびマスフラグメントグラムから同定された。

パルチン酸中の少量の不純物は同族体に特有なフラダメントすなわち脂肪酸 $m / e$ 60, フルカン $m / e 71$, アルケン m/e 97 に多重イオン検出器を設定することにより濃縮することなく高感度で選択的

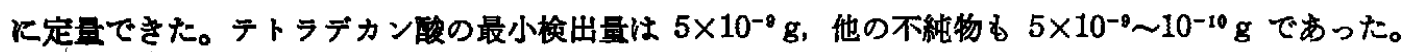
奄子衙整イオン化によるマスフラグメントグラフィーはそれぞれの同族体について一つの特徽ある $m / e$ に設定することにより同族体個々の定量を行なえる利点がある。本法は高純度ステフリン酸などの他の 脂肪酸中の微量不純物の定量にる利用できる。

\section{1 精}

脂肪酸恃自然界に多く存在し, 工業的にす広く利用されてお り，これまで摔やの分析法が適用されている。とくにガスクロ マトグラフィーKよる分析は James, Martin1) によるガスクロ マトグラフィーK関する最初の報文に発表されたのを始めとして 厸く検討された。

脂肪酸柱カルボキシル基による担体への爱着が強いため, 测定 上程↔の閣題が提起されてだり，早くからメチルエステルなどの 馀空体にしたのらガスクロマトグラフ測定する方法が行なわれて

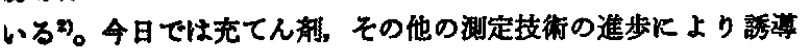
体にせゲ，直妾ガスクロマトグラプ測定し，再現性ある結果が得 られている゙。現在までに報告された脂肪酸およびそのエステル カガスクロマトグラフィーに成する研究はきわめて多い。

ガスクロマトグラフィー-筫量分析法での脂肪酸の测定はお。

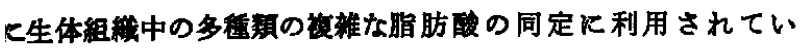
3) - )。

これらの测定の傈榊に用いられる高純度脂肪酸試薬中にも多く ら不純物が存在し，これら一部は脂肪酸の同矮体と考えられるが その他の不純物についての知見江得られていない。近年，定量の 量化，精密化飞とるない標進として用いる高純度脂肪酸中の微 にの不純物の分析法を確立することが工業界で強く要望されてい

* 中央大学理工学部, 112 東京都文京区春日

1) A.T. James, A. J.P. Martin, Biochem. J., 50, 679 (1952).

2) F. R. Cropper, A. Heywood, Nature, 172, 1101(1953).

3) 丸山正生, 坂口ヒ口子, 分析化学, 15, 56(1966).

4) J. Jacob, J. Chromatogr. Sci., 13, 415(1975).

5) J.M.B.Apon, N. Nicolaides, ibid., 13, 467(1975).

6) J. J.Myher, L.Marai, A. Kuksis, Anal. Biochem., 62, 188(1974).
る。またその精製法を確立するためにる存在する不純物の種類と その量を明らがすること恃重要である。

しかし，存在する微量不純物を漫繀，分離などの前处理をする

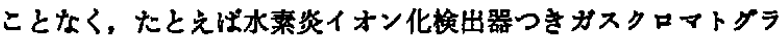
フで直接定量すること性困難である。そこで本研究においてはま ず存在する微量不純物の同定をガスクロマトグラフィー一筫量分 析法で行ない，同族体の定量にはマスフラグメントグラフィーが 有奻であると考党た。そこでこれらの手法を用いて脂肪酸を誘導 体炕せず，检量不純物を迅速比直接定量するための基整的条件に ついて高純度パルミチン酸を測定対象として検討し,さらにこの 分析法を用いて各種の高純度パルミチン酸中の不純物の種類とそ の罿を明らか比した。

\section{2 英 聵}

\section{1 测定試料および弪蕰}

測定陚料の高純度パルミチン酸には市眅の試薬特級 $(A \sim E)$ お よびガスクロマトグラフィー標準用（F，G）の計７释を用いた。 $\mathrm{CH}_{3}\left(\mathrm{CH}_{2}\right)_{n} \mathrm{COOH}(n=2 \sim 16)$ の脂肪酸およびそのメチルエステ ル, $\mathrm{C}_{n} \mathrm{H}_{2 n+2}(n=15 \sim 24)$ の飽和岸化水菜, $\mathrm{C}_{n} \mathrm{H}_{2 n}(n=15 \sim 24)$ の 不飽和炭化水素には和光純薬製垎よび東京化成製の標楛品を用い た。溶媒注圾試薬特級クロロホルムを使用した。

\section{2 装管およひ实騲方法}

2.2.1 ガスクロマトクラフィーー蕉基分析法：ガスクロマトグ ラフー質量分析計（以下 GC-MS と略記する）は日電バリアン製 NEVA GC-MS TE-600 型を種々検討の結果, 下記条件で使用 した。

$\mathrm{GC}$

分離管：ガラス整， $2 \mathrm{~mm} \times 200 \mathrm{~cm}$

固定相：FFAP； 4\%/ネオンルブ NS(80〜100 メッシュ)

分離管温度 : $50 \rightarrow 230^{\circ} \mathrm{C}\left(10^{\circ} \mathrm{C} / \mathrm{min}\right)$ 
キャリヤーガス: He, $12 \mathrm{ml} / \mathrm{min}$

MS-

筫量籁囲 : $10 \sim 400$

全笔子電流 : $180 \mu \mathrm{A}$

贯通電流 : $150 \mu \mathrm{A}$

電子加速軍任 : $70 \mathrm{~V}$

イオン加速電压 : $10.6 \mathrm{~V}$

二次電子增倍管䉓压 : $-2.5 \mathrm{kV}$

試料はリロロホルムに溶解し，1 wto として測定に供した。

2.2.2 带敢法 : 試料の港縮に恃島津 CZ-1 薬品精製装置を用 いた。冷却にはシャーブ電子冷熱装盖 TE-60を用い,メタノー ルー水を循謤して $0^{\circ} \mathrm{C}$ て行なった。試料忹内径 $5 \mathrm{~mm} \phi$ のハイ レックス製ガラス管に $30 \mathrm{~cm}(5.6 \mathrm{~g})$ になるように充てんし，移 動速度 $4.4 \mathrm{~cm} / \mathrm{hr}$ で約 100 回移動させたのち濃編部（下端から $1 \mathrm{~cm}$ )を取り，測定に供した。

\section{3 英験結果および考㳟}

\section{1 不維物の同定}

3.1.1 筫且スペクトルによる同定：パルミチン酸試料の $1 \%$ 溶液を GC-MS により全イオン電流検出器 (以下 TIC と略婄す る）を用いて㑚定した場合，不純物は成分数，量とる比較的多く 検出されたが，微量成分の同定を行ないやすくするため带虽法に より不純物を約 5 倍に婊縮したるのを用いた。国定相として脂肪 酩の分離に良好な FFAP をリン酸処理したネオンルブ NS に含 浸したものを用いた。広い沸点範囲の不純物を効率上く分離する ため分離管沮度は 2.2.1 に示した昇温条件でクロマトグラムを 測定した。

7 種のバルミチン酸試料の中で不綪物の成分数，含有量とも比 校的多いバルミチン酸(A)の瀑䑿物のクロマトグラムを一例とし て图1に示す。試料(A)中の不純物は 12 種検出され，それぞれ の不純物を保持時間の短い䫀に（a)〜（1）までの記号で示した。 これらの不純物についてそれぞれの筫䡒スペクトルをとり同定を

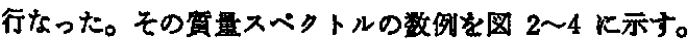

図2に示した不純物 (c)の質量スベクトルはメキレンに相当す る 14 筫量単位ずつ離れたビーク群が現われ，各群とも $\mathrm{C}_{n} \mathrm{H}_{2 n+1}$ の強度がもっとも強く，質量数が大きくなるにしたがって次第に 強度が隇ずる。これ江㥎和非環式炭化水素に典型的な形であり，

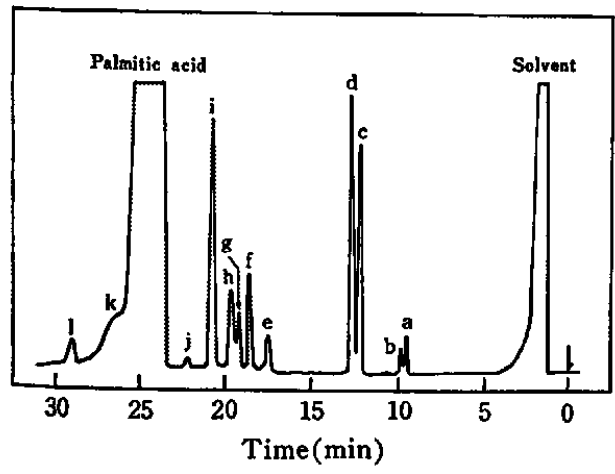

Fig. 1 Chromatogram of palmitic acid(A) Stationary phase : FFAP Column temp. : $50 \rightarrow 230^{\circ} \mathrm{C}\left(10^{\circ} \mathrm{C} / \mathrm{min}\right)$
ピーク群の減少曲線の途中に強度の強いビークが現われていない ことは值鎖であることを示している。さらに分子イオンビークが $m / e 240$ であることから不純物 (c)はへブタデカンと同定され た。

因 3に示した不純物 (d)の筫量スペクトルにおいてる（c)と同 様に 14 貝量単位ずつに強度の強いフラグメントビークを示す。 しかしこの場合は強度の強いビークの窝量数は飽和岸化本莱より $m / e 2$ 少ない $\mathrm{C}_{n} \mathrm{H}_{2 n-1}$ であり，さらにオレフィンの脱離により形 成される $\mathrm{C}_{n} \mathrm{H}_{2 n}$ の強いフラダメントピークが筧测される。この ことは不飽和非㻴式炭化水素であることを示し，さらに分子イオ ソピークが $m / e 238$ であることから不純物 (a) はーブタデセン と同定された。

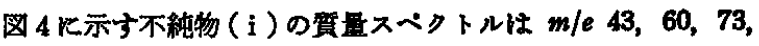
129 にそれぞれ強度の強いフラグメントビークを示す。 $m / e 60$ は脂肪酸 $\left[\mathrm{HO}-\mathrm{OH}=\mathrm{CH}_{2}\right]^{+}$に起因する再配列ピークであり, m/e 73, 129 は $\left(\mathrm{CH}_{2}\right)_{n} \mathrm{COOH}$ の $n=2,6$ 飞相当する。さらに $n=3,4$, 8 に相当する $m / e$ 87, 101,157 Kすフラグメントピークを与 える。上記のことと $m / e 228$ に分子イオンピークを示すことか ら不純物 (i ) はテトラデカン酸と同定された。

その他の不純物についても質量スベクトルから同漛に同定し,

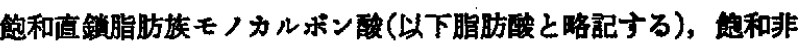

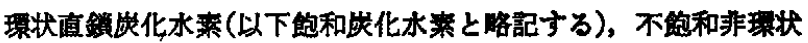

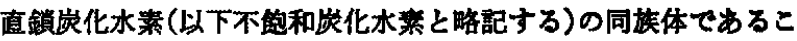
そがわかり，その記号に対応する化合物名を表 1 に示した。他の パルミチン酸 (B)〜 (G)の試料についても不純物量の違いはある がその程類は(A)と同棣であった。

3.1 .2 保持時间による同定: 寊量スペクトルの解析結果から 含有される不純物は脂肪酸，铇和，不飽和炭化水素の同族体です ることがわかった。ガスクロマトグラフィー（昇温）においては

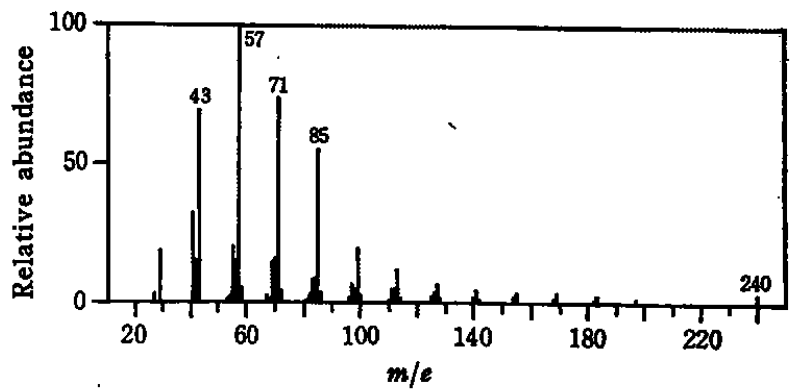

Fig. 2 Mass spectrum of impurity (c) in palmitic acid

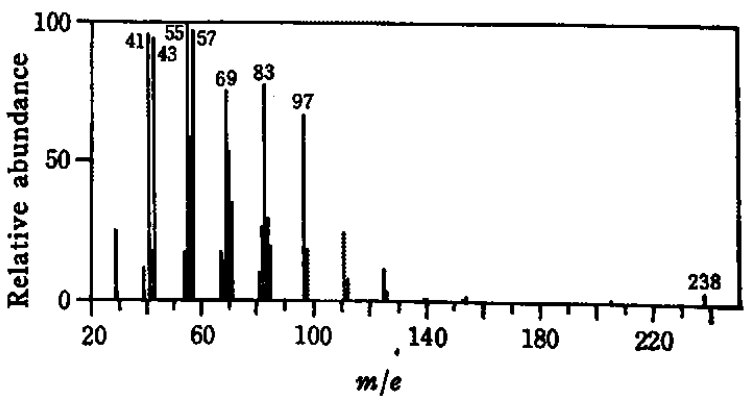

Fig. 3 Mass spectrum of impurity (d) in palmitic acid 
同族体間では炭菜数と保持時間との間には直線関保がある。この ことを利用することにより保持時間から不純物を同定できる。さ らに脂助酸試料をメナルエステル化すれば不純物である脂肪酸の みがメチルェステル化されるため、分離管から早く溶出し，炭化 水菜䝿の保持時間は变わらない。このことかららクロマトグラム上 に現われる脂肪䜵，炭化水絭ビークを明確に同定できる。

さらにメチルニステル化したるののクロマトグラムを比慗する 利点柱成分であるパルミチン酸ビークの中に炭化水素などの不 練物が一緒に溶出しているかどらかを知ることができることであ る。图 5 に試料(A)の灌縮物をメチルエステル化し，図 1 と同一 年件で測定したクロマトグラムを示す。図 1 と比較したとき不綿 物 (a), (b), (c), (d), (e), (f), (h) の保持時間住変わら朴 が: (g), (i ), ( j), (k), (1)のビークは土チルェステル化した

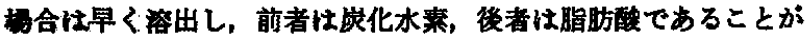
明確になる。さらに図 5 のパルミチン酸の保持時間のところに未 反応のバルミチンン酸が少量穓出されたが，他の不純物は榆出さ れなかった。このことは質量スへフトルからす碓からられた。

3.2 不耧物のマスフラタメントクラフィー

含有される不級物恃脂肪酸，铇和，不的炭化水莱の同族体で あり，同族体の賈量スペクトルは類似していることから各同族体 について特有なフラグメントビークを一種選択し，多重イオン检 出譽を用いて揤定すれば，クロマトグラフ的に分離の熹い場合で

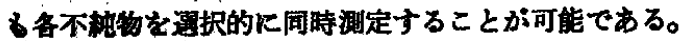

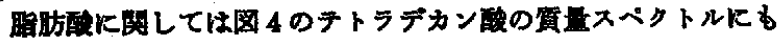

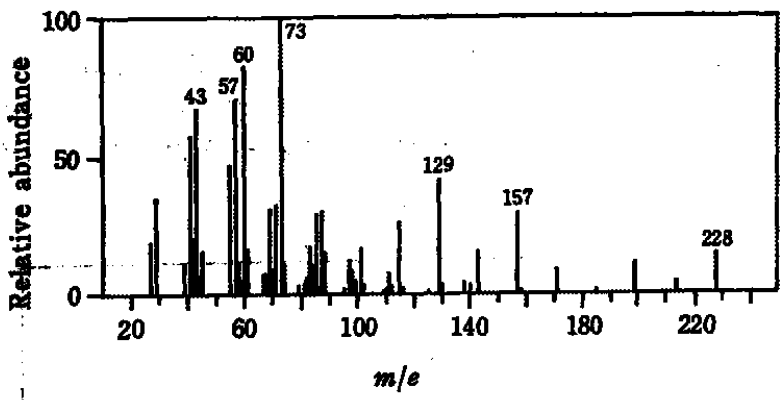

Fig 4 Mass spectrum of impurity ( $i$ ) in palmitic acid

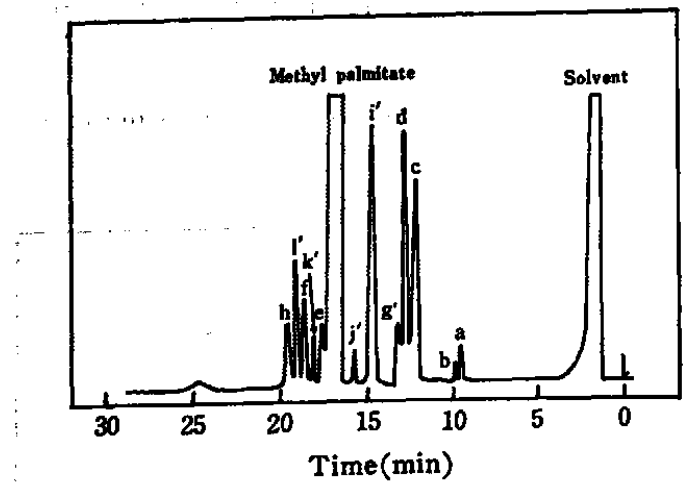

Fig. 5 Chromatogram of methyl esterificated palmitic acid (A)

Stationary phase : FFAP

Column temp. : $50 \rightarrow 230^{\circ} \mathrm{C}\left(10^{\circ} \mathrm{C} / \mathrm{min}\right)$
みられるよらに m/e 60，73，129 に強いフラグメントピークを 生ずる。測定に利用するフラグメントピークはガスクロマトグラ フに用いた固定相の微罯溶出に依存するバックグランドとして現 われるフラグメントピークも考感に入れ，これらフラグメントピ 一クの中で高い感度が得られ，しかる他の含有成分である炭化水 秦，不飽和炭化水秦に対して選択的であるすのが好ましい。図 2,3 亿示したように炭化水素は $m / e 60 ， 73 ， 129$ Kはフラグメ ントピークを生じないため,これらは脂肪酸に選択的である。こ の中でマスフラグメントグラムを比較した場合芯答す大きく、べ ースラインも安定である $m / e 60$ を脂肪酸測定のフラグメントピ ークとして選んだ。

飽和炭化水素は $m / e 57,71,85$ K強いフラグメントピークを 示す。しかしこれらの $\mathrm{m} / \mathrm{e}$ で䈳肪酸および不的和炭化水素に ついてるラグメントピークを与える。しかる，これらのフラグ メントピークの選択性はどの $\mathrm{m} / \mathrm{e}$ に成してるほほ同しである め $S / N$ が良好な $m / e 71$ を選んだ。

不飽和炭化水素は $m / e 55,69,83,97$ の法か飽和灰化水素に 現われる $m / e$ 57, 71,85 にる強いフラグメントピークを示す。 相対強度は $m / e 55,83$ が大であるが垶択性, $S / N$ とも $m / e 97$ が良好なため $m / e 97$ を選んだ。

つぎにこの選択されたフラグメントピーク $m / e 60,71,97 て ゙$ 脂肪酸，的和炭化水素，不的炭化水素の混合物について湘定し たマスフラグメントグラムのー例を図 6 K示す。TICではペン タデカンとペンタデセンおよびヘブタデカンとーブタデセンは完
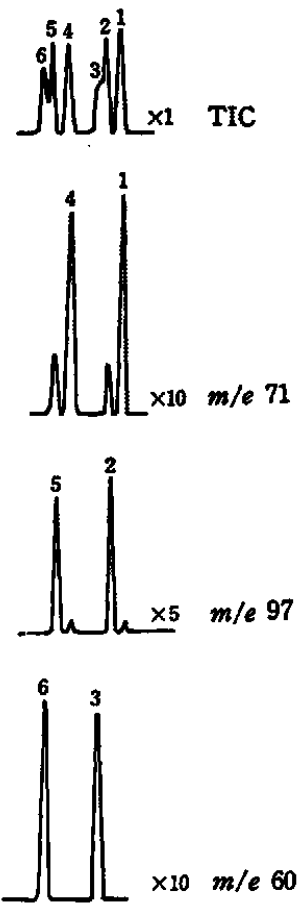

Fig. 6 Mass fragmentgrams of alkane, alkene and fatty acid

1 : Pentadecane, 2 : Pentadecene, 3 : Butyric acid, 4 : Heptadecane, 5 : Heptadecene, 6 : Valeric acid Sample size : $1 \times 10^{-8} \mathrm{~g}$ 
全に分離するが，ペンタデセンと酪酸およびヘブタデセンと吉草 酸は完全に分㕍しない。このよらにガスクロマトグラフ的に分離 しない場合です m/e 60 は脂肪酸に特有であり，前に述べたよ

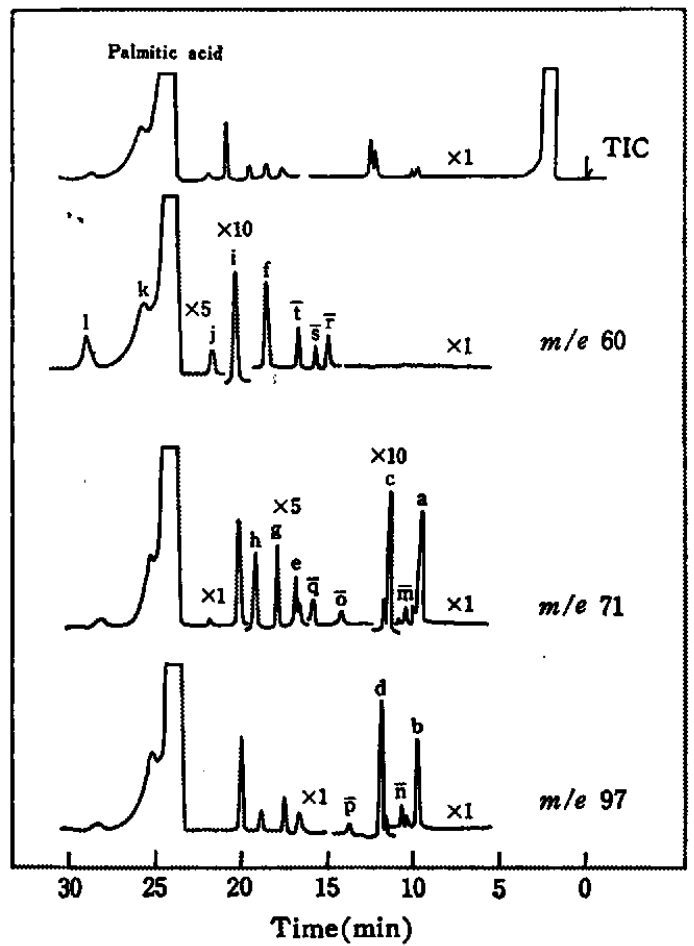

Fig. 7 Mass fragmentgrams of palmitic acid (A)
に他の含有成分である炭化水素はこの $m / e$ でビーク ため， $m / e 60$ に設定し、 、スフラグメントグラフィーを行なえ ば非常に選択的に脂肪酸のみを検出できる。飽和炭化水素に特有 な $m / e 71$ は図6にるみられるよ5に不飽和库化水案にも応答を 与え, 脂肪酸については図 6 では店答を示していないが多量の场 合は応答を示す。この $\mathrm{m} / \mathrm{e} 71$ の応答は飽和炭化水素を 1 とした とき,この測定の䈏囲内で注不飽和炭化水素は $1 / 5 \sim 1 / 8$, 脂肪酸 は 1/5〜1/100であった。また不飽和炭化水素に特有な $m / e 97$ す 同粎に不飽和炭化水素の応答を 1 としたとき, 䭒和炭化水素は 1 / 6〜1/20, 脂肪酸は $1 / 5 \sim 1 / 100$ であった。

本法で恰和炭化水素と不飽和炭化水素のガスクロマトグラフ ィーでの分離は良好であるため両者の剆定には問題はない。しか しながら埸合によってはクロマトグラフ的に分離せず，慨和然化 水菜, 不飽和炭化水素, 脂肪酸の 2 成分または 3 成分が完全火 重なって溶出する。この場合でもあらかじめ標準物質について各 $m / e$ での応答の比を求めておき二元一次また㤝元一次方程式を 解くことにより定量を行ならことができる。

つぎに多重イオン榙出器を用いて $m / e$ 60，71，97 飞設定し， パルミチン酸試料(A)Kついてマスフラグメントグラフィーを行 なった。多重イオン検出器で梳高感度揤定が行なえるため, 図 7 にみられるよらに TIC でははとんど検出されなかった成分が㭘 出された。これら特有な $m / e$ および同族体の炭真数と保持畤間 の関係を用いでスフラタ゚メントグラムがら同定され，さきに述 へた 12 種に加えて，さらに8種の不純物を同定できた。この不

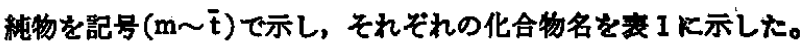
以上のよらな手法を用いることにより脂肪酸中に存在する主要

Table 1 Impurities detected in high purity palmitic acid

Sample(ppm)

Component

$\overline{\mathbf{r}}$ Octanoic acid

s Nonanoic acid

$\overline{\mathbf{t}}$ Decanoic acid

$f$ Dodecanoic acid

i Tetradecanoic acid

j Pentadecanoic acid

k Heptadecanoic acid

1 Octadecanoic acid

Alkane

$\begin{array}{cl}\text { a } & \text { Pentadecane } \\ \overline{\mathbf{m}} & \text { Hexadecane } \\ \mathbf{c} & \text { Heptadecane } \\ \overline{\mathbf{o}} & \text { Nonadecane } \\ \overline{\mathbf{q}} & \text { Heneicosane } \\ \mathbf{e} & \text { Docosane } \\ \mathbf{g} & \text { Tricosane } \\ \mathbf{h} & \text { Tetracosane } \\ \text { Alkene } \\ \mathbf{b} & \text { Pentadecene } \\ \overline{\mathbf{n}} & \text { Hexadecene } \\ \mathbf{d} & \text { Heptadecene } \\ \overline{\mathbf{p}} & \text { Nonadecene }\end{array}$

\begin{tabular}{ccc}
\hline $\mathrm{A}$ & $\mathrm{B}$ & $\mathrm{C}$ \\
$\mathrm{GR}^{(\boldsymbol{a})}$ & $\mathrm{GR}$ & $\mathrm{GR}$ \\
\hline
\end{tabular}

D

E

225
143
330
860
10500
1320
1125
6450

50
78
725
1120
16500
2710
$<50$
1745

$$
<30
$$$$
<30
$$

50

$$
<30
$$

$<30$

$<30$

240

125

660

5500

16000

1750

1900

4250

690

1900

12750

860
60
8500
133
246
975
3900
3250

710

173

2000

$<25$

$<25$

340

1440

25

\section{$<25$}

$<25$

$<25$

$<25$

$<25$

$<25$

$<25$

395

420

270

$<25$

$<25$

$<25$

540

990

185

900

900

965

8500

50000

$$
<25
$$

$<25$

$<25$

$<25$

$<25$

$<25$

540

1600

$<25$

$<25$

$<25$

$<25$

288

$<25$

$<25$

$<25$

$<25$

$<25$

$<25$
$<25$

$<25$

$<25$

$<25$

$\underset{\text { SG) }}{\mathbf{F}} \quad \mathbf{G}$

SG

$\begin{array}{rr}<30 & <30 \\ <30 & <30 \\ <30 & <30 \\ 210 & <30 \\ 2100 & 315 \\ 8500 & 1025 \\ 30500 & 660 \\ 3450 & 1900\end{array}$

$\begin{array}{ll}<25 & <25 \\ <25 & <25 \\ <25 & <25 \\ <25 & <25 \\ <25 & <25 \\ <25 & <25 \\ <25 & <25 \\ <25 & <25 \\ & \\ <25 & <25 \\ <25 & <25 \\ <25 & <25 \\ <25 & <25\end{array}$

a) Guaranteed reagent.

b) Standard for gas chromatography. 


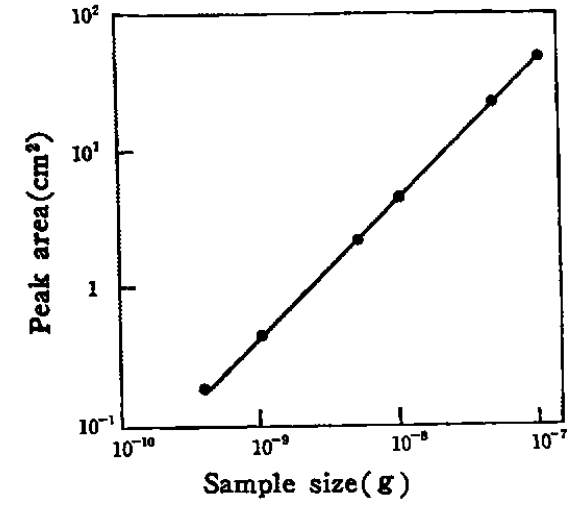

Fig. 8 Relationship between sample size of tetradecanoic acid and response $(m / e 60)$

\section{な不純物を同定ナることができる。}

\section{3 不赫物の定量}

3.3.1 不坉物の定司法：多重イオン検出器を用い,それぞれ の同疾体に特有な $m / e$ K設定し，検出された化合物 20 種につ いて試料最と忘答の䦎係站べた。一例としてテトラデカン酸を

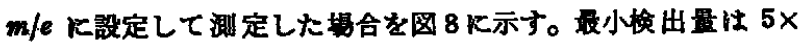

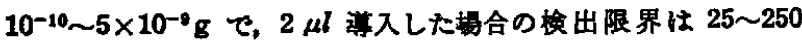
ppmであった。これらの蹎線性，再現性とも良好な結果が得ら れた。

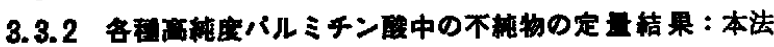

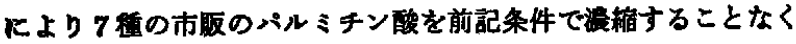
直接定量した結果，その不純物含量恃素1儿示したよらである。 相対的に多く含まれていた不純物性テトラデカン酸〜オクタデカ ン睃、ーブタデカン、へブタデセンであった。バルミチン酸はヤ シ油などの天然物を分解し，分離、精製してつくられ，利用され
ているが微量ではあるが炭素数奇数の脂肪酸，炭化水素が焕出さ れたことは興味あることである。

\section{4 結 言}

市眅の特級試薬, ガスクロマトグラフ镖準用などの高純度パル ミチン酸中の不純物の同定, 定量飞 GC-MS 法を利用すること を試み、この方法が多数の微量不純物を同時定量できるきわめて 有效な分析法であることを確かめた。

質量スペクトル，クロマトグラムの保持時間和よびマスフラグ メントグラムから不純物として飽和直鎖モノカルボン酸, 飽和非

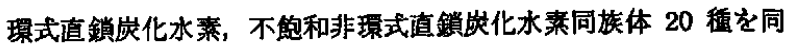
定した。

不純物の定量にはおの括のの同族体に特有なフラグメントビー クとして脂肪酸 $m / e 60$, 飽和炭化水素 $m / e 71$, 不飽和炭化水 粪 $m / e 97$ に設定し, 多重イオン検出器を用いて直接, 試料中の

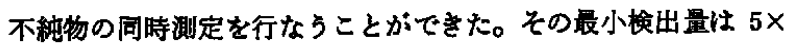
$10^{-9} \sim 5 \times 10^{-10} \mathrm{~g}$ であり，誘迸体にせず直接測定しても㖟着など の影签なく再現性よく，高感度で定量できた。脂肪酸に特有なつ ラグメントピーク $m / e 60$ は炭化水素に対して選択的であり,ガ スクロマトグラフ的に炭化水素と分離しない場合です脂肪酸を選 択的に検出できる。

本法を用いて測定した試薬中の不純物含量は 0.4 6.3\% で比 較的多く検出された。不純物としては $\mathrm{C}_{12} \sim \mathrm{C}_{18}$ の脂肪酸はどの 武料でるその含有量恀かった。しかし炭化水慗含有量江試料任 よりかなりの美がめり，ガスクロマトグラフ標準用のものは炭化 水莱含量はすべて検出限界以下であった。

以上の結果から明らかなよらに本分析法は他の高純度脂肪酸中 の不純物の同定・定量飞る十分租用することができる。

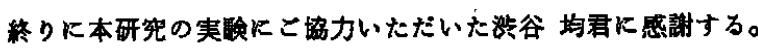

(1977 年 10 月, 日本分析化学会第 26 年会(一部)発表)

\title{
Determination of a Small Amount of Impurities in High Purity Palmitic Acid by Gas Chromatography-Mass Spectrometry
}

\author{
Michiko KaKemoto and Masao MaruYama
}

\author{
Department of Industrial Chemistry, Faculty of Science and \\ Engineering, Chuo University; Kasuga, \\ Bunkyo-ku, Tokyo 112 Japan
}

Idntification and determination of a small amount of impurities in the commercial reagent grade and GC standard palmitic acid were carried out by gas chromatography-mass spectrometry. Twenty kinds of impurities, fatty acids $\left(\mathrm{C}_{n} \mathrm{H}_{2 n+1} \mathrm{COOH}, n=8 \sim 18\right)$, alkanes $\left(\mathrm{C}_{n} \mathrm{H}_{2 n+2}\right.$, $n=15 \sim 24)$ and alkenes $\left(C_{n} \mathrm{H}_{2 n}, n=15 \sim 19\right)$ were identified from their mass spectra, retention time and characteristic $m / e$ of mass fragmentgrams.

A small amount of impurities in palmitic acid was determined sensitively and selectively without any preconcentration of the impurities by setting the multiple ion detector to their characteristic fragments for homologues, fatty acid to $m / e=60$, alkane to $m / e=71$ and alkene to $m / e=97$. The minimum detectable amount for tetradecanoic acid was found to be $5 \times 10^{-9} \mathrm{~g}$ and other impurities $5 \times 10^{-8} \sim 5 \times 10^{-10} \mathrm{~g}$. This method is available for determining a small amount of impurities in other high purity fatty acid such as stearic acid. 